УДК [378.015.311:159.947]:3

DOI:

Алла Сеник, кандидат педагогічних наук, старший викладач кафедри психології і сочіальної роботи Західноукраїнського національного університету

\title{
ПРОФЕСІЙНО-ТВОРЧА САМОРЕАЛІЗАЦІЯ ЗДОБУВАЧІВ ВИЩОЇ ОСВІТИ ЗАСОБАМИ ТРЕНІНГУ
}

У статті розглянуто одне з важливих питань освітнього процесу, щ⿻ полягає уз 'ясуванні актуальності використання тренінгу як засобу, щьо сприятиме якісній професійно-творчій підготовці здобувачів вищьӧ освіти. У матеріалах публікації підкреслено, щуо, наприклад, у живих організмів творчість проявляється у формі пристосування до змін у навколишньому середовищзі, а творчість у суспільстві є вищою формою прояву діяльності людини щуодо створенню нового та раніше не існуючого. Цінність тренінгу для розвитку творчості за своєю природною сутністю полягає в оновленні та змінах. Автором проаналізовано особливості використання методичних засобів, щуо використовуються у тренінгу особистісного зростання. У статті значну увагу приділено креативності здобувачів вищої освіти, щуо уможливлює прояв оригінальності мислення, збагачення уяви, почуття гумору, розвитку естетичних иінностей, щчо є значущим для підготовки здобувачів вищої освіти. Істотною умовою формування у здобувачів вищої освіти здатності до професійно-творчої самореалізації визначено саме актуалізацію здатності до самовладання і впевненості у собі.

Ключові слова: особистість; тренінг; креативність; творчість; професійна самореалізація; творча самореалізація.

Jim. 6.

Alla Senyk, Ph.D.(Pedagogy), Senior lecturer of the Psychology and Social Work Department of Western Ukrainian National University

\section{PROFESSIONALAND CREATIVE SELF-REALIZATION OF HIGHER EDUCATION APPLICANTS BY TRAINING MEANS}

The phenomenon of development of professional and creative self-realization of applicants is a philosophical, psychological, pedagogical and socio-cultural problem, it is logically determined, because self-realization is a criterion of personality quality. The instruments of the value system of modern higher education seekers are culture, which includes knowledge, rules, norms and patterns. The need for self-education and self-development of modern applicants is due to increasing general cultural and professional requirements of society.

The materials of the article consider one of the important issues of the educational process, which is to clarify the relevance of the use of training as a means to promote quality professional and creative training of higher education. The content of the publication highlights aspects of the fact that the internal qualities of the individual are formed under the influence of external stimuli and incentives for self-development. Thus, the training is considered as a means to develop higher education students' ability to professional and creative self-realization.

The author analyzes the features of using of methodological tools used in personal growth training. The value of training for the development of creativity in its natural essence lies in renewal and change. The materials of the publication emphasize that in living organisms, for example, creativity is manifested in the form of their adaptation to environmental changes, and creativity in society is the highest form of human activity to create new and non-existent. The article pays considerable attention to the creativity of higher education, which allows the manifestation of original thinking, enrichment of imagination, sense of humor, development of aesthetic values, which is important for the preparation of higher education. An essential condition for the formation of higher education students' ability to professional and creative self-realization is the actualization of the ability to selfcontrol and self-confidence.

Keywords: specialty; professional self-realization; creative self-realization; training.

П остановка проблеми у загальному вигляді та її зв'язок із важливими науковими чи практичними завданнями. Феномен розвитку професійно-творчої самореалізації здобувачів становить філософську, психолого-педагогічну та соціально-культурну проблеми, i це є логічно обумовленим, адже самореалізація виступає критерієм якості особистості.
Інструктами ціннісної системи сучасних здобувачів вищої освіти є культура, що включає знання, правила, норми та зразки. Потреба у самоосвіті і саморозвитку сучасних здобувачів обумовлена підвищенням загальнокультурних та професійних вимог з боку суспільства. Варто підкреслити, що внутрішні якості особистості формуються під впливом зовнішніх стимулів та стимулів саморозвитку. 
У нашому дослідженні розглядаємо саме тренінг як засіб, що уможливить розвинути у здобувачів вищої освіти здатність до професійнотворчої самореалізації.

Аналіз основних досліджень і публікацій. Тематика означеної нами проблеми висвітлена у працях вчених різного напряму. Так, наприклад, Л. Рибалко, Р. Черновол-Ткаченко, Г. Твердохліб наголошують на тому, що проблема самореалізації людини, її розвитку й самовдосконалювання посідає чільне місце у філософії різних епох. Вчені відстоюють думку про етику самореалізації, у межах якої індивідуальні здібності людини завжди протиставляються вимогам суспільства, тобто вчинки людини тісно пов'язані з усвідомленням нею значущості власного "Я" у навколишньому світі, персональною відповідальністю за наслідки діяльності й поведінки [5].

Нашу увагу також привернули дослідження О. Остапчук, де досить детально висвітлено тематику свободи професійного самовизначення, розкрито аспекти творчості як складника процесу самореалізації та модельності педагогічного процесу [3]. Нам імпонує думка вченої про потребу у технологізації міжособистісної взаємодії для творчості та пошуку власної неповторності у професійній діяльності. Це й зумовило вибір теми нашого дослідження.

Формування мети статті. Мета викладу матеріалу статті полягає у вивченні наукового досвіду щодо професійно-творчої самореалізації здобувачів вищої освіти засобами тренінгу.

Виклад основного матеріалу дослідження 3 повним обгрутуванням отриманих наукових результатів. Однією зі складних $\mathrm{i}$ ключових у сучасній освітній діяльності $\epsilon$ проблема особистості та їі розвитку. Огляд понятійного апарату дослідження ми розпочали зі з’ясування такої категорії, як “особистість”, що визначено у словниковій літературі багатогранним поняттям, що не має однозначного визначення. Попри всю різноманітність розуміння виділяють наступні загальні положення щодо категорії “особистість”: біологічне розуміння особистості існує в особистості як:

- особистість соціальна: природні характеристики виступають у структурі особистості як їі соціально обумовлені елементи;

- особистість - як системна якість, якої набуває індивід у взаємодії з соціальним оточенням;

- особа може бути зрозумілою лише в системі стійких міжособистісних зв'язків, що опосередковуються змістом, цінностями і сенсом спільної діяльності;
- особистість народжується 3 прагнення до максимальної персоналізації. У будь-який діяльності людина прагне до прояву своєї індивідуальності, а неможливість реалізації цієї мети приводить до пошуку нових можливостей в собі самому або у предметній діяльності;

- джерелом розвитку особистості у системі міжособистісних відносин виступає суперечність між потребою в індивідуалізації і зацікавленістю людини інтегруватися у значущу для неї соціальну групу, тобто суперечність між бажанням людини бути самою собою і прагненням виправдати очікування суспільства;

- характер розвитку особистості формується пропорційно тому рівню розвитку і цінностям тієї групи, до якої вона включена.

Особистість як суб'єкт власної життєдіяльності характеризується активністю, самостійністю, відповідальністю, ініціативністю, свідомістю, цілепокладанням, саморегуляцією тощо. Беручи до уваги вищевказане, саме в рамках життєдіяльності здобувачів вищої освіти здійснюється процес самореалізації.

Самореалізація - це одна з основних цінностей життєдіяльності кожної людини, що відображає їі прагнення найбільш повно проявити свої здібності і потенціали, втілити їх в життя у процесі продуктивної діяльності. Самореалізація - це процес виявлення, осмислення та здійснення особистістю своїх потенційних позитивних можливостей: формування мети і розробка стратегій для ¥ї здійснення; прояв себе і своєї індивідуальності у тій чи іншій сфері за допомогою усвідомлюваних можливостей, результатів попередньої діяльності, коригування та побудови подальшого плану життя.

Професійно-творча самореалізація здобувачів вищої освіти, на наш погляд, є дуже складним явищем. Творчість у суспільстві визначається як прояв вищої форми діяльності людини щодо створення будь-чого нового, чого ніколи раніше не існувало. Ми поділяємо погляди вчених [4], [5], [6] про те, що не існує діяльності, яка була б абсолютно творчою, адже будь-яка конкретна форма людської діяльності включає у себе творче і нетворче, продуктивне і репродуктивне.

Підготовку здобувачів вищої освіти до самореалізації себе як професіонала ми визначаємо як суспільно-значущий, безперервний, цілеспрямований процес розкриття та ефективного використання особистістю власного творчого потенціалу, що ефективно відбувається завдяки тренінговій роботі.

Сучасний здобувач як майбутній фахівець має володіти такими якостями, як стресостійкість, 
вміння адаптуватися до різних умов роботи, мати здібності до дипломатичної взаємодії тощо. Так, наприклад, у межах обраної професії під час участі у тренінгах (як у ролі учасника, так і виконуючи роль організатор або тренера), у здобувачів вищої освіти формуються комунікативні здібності, відбувається кар'єрний ріст, досягається певний соціальний статус. Під час бесіди зі здобувачами ми з'ясували, що вони вважають незатребуваною у професійній діяльності схильність до творчого начала. Саме тому під час освітнього процесу маємо довести майбутньому фахівцю, чому так важливо вміти формувати нове знання, і де саме це може стати у нагоді на практиці.

Варто підкреслити, що методично організований тренінг спричиняє низку змін:

- По-перше, розвиваються й оптимізуються комунікативні здібності, що відбиваються у навичках спілкування i у прийомах міжособистісного оцінювання;

- по-друге, завдяки участі у тренінгах у здобувачів вищої освіти зростає соціальнопсихологічна компетентність, формуються уміння орієнтуватися у соціальних ситуаціях, розуміти інших людей, обирати адекватні форми спілкування;

- по-третє, підвищується ефективність оперативної (регулювання своєї поведінки у конкретних короткочасних ситуаціях) i перспективної саморегуляції (упродовж тривалого проміжку часу);

- по-четверте, долаються бар'єри і захисні механізми несвідомого, що призводить до труднощів у самореалізації;

- по-п'яте, умови тренінгу і досвід участі повертають особистість до самопроцесів у реальному житті: самоаналізу, саморегуляції, самоосвіти та самовиховання.

Нам імпонує думка психологів з приводу того, що взагалі вибір форм самореалізації обумовлений трьома основними типами ідентифікації:

- “мати”, що базується на фізіологічних потребах людини;

- “досягати”, заснована на потребах людини у визнанні і повазі;

- “бути”, в основі чого є потреби у самотворенні і самоактуалізації.

У першому випадку самореалізація набуває характеру матеріального благополуччя, у другому - визначає напрям людини на досягнення успіху, а в третьому виступає певним стимулом активності у реалізації своєї унікальної творчої індивідуальності.

Цінність тренінгової роботи у цьому аспекті полягає у тому, що здобувачі вищої освіти як учасники намагаються усвідомити і подолати свої соціально-психологічні проблеми, що перешкоджають розв'язаннюжиттєвих іпрофесійних завдань. Кожен учасник такого тренінгу за допомогою інших учасників і тренера може усвідомити свої страхи, позбутися своїх внутрішніх бар'єрів, зрозуміти, як його сприймають навколишні. Це допомагає виявити i y майбутньому ефективніше застосовувати свої позитивні якості, сформувати реальну оцінку своїх здібностей, вивчити свої помилки і недоліки.

Основним результатом успішно проведеного тренінгу для формування у здобувачів вищої освіти навичок професійно-творчої самореалізації має бути: зростання адекватної самооцінки, зняття бар'єрів у спілкуванні, зміна основної стратегії поведінки. Усі ці фактори створюють основу для внутрішнього особистісного зростання і розвитку.

Також варто звернути увагу на те, що усі тренінги покликані створити сприятливі умови для особистісного зростання їх учасників [1], [2]. Для тренінгу, який ми маємо на увазі в межах нашої теми, важливим є принцип руху. Для цього доречно, на нашу думку, використовувати психогімнастику, групову дискусію або i елементи, рефлексивні й медитативні техніки, ігри та ігрові прийоми. Однак акцент переважно треба робити на самому процесі саморозвитку i професійному творчому зростанні.

Розглянемо докладніше зміст основних технік і вправ. На початку занять можуть бути проведені рухливі ігри, невербальні техніки, психогімнастичні вправи, що дають змогу створити високий рівень відкритості, довіри, емоційної свободи і такий стан кожного здобувача вищої освіти, що допомагав би успішно працювати, просуватися вперед у професійному плані.

Ось приклад такої розминки.

Вправа “Зустріч очей”. Інструкція. Пропонуємо активізувати зорову діяльність, привітаємо один одного. Для цього необхідно упродовж хвилини охопити зором якомога більшу кількість учасників групи та привітати різними рухами, можна вітати одного учасника кілька разів.

Для обговорення пропонуємо використати такі питання: як ви почувалися під час вправи? Контакт 3 ким із членів групи вам запам'ятався? Що до цього призвело? тощо.

Ще одним з важливих аспектів у професійнотворчій самореалізації здобувачів вищої освіти $є$ процес формування і розвитку “Я-образу”. “Яобраз” - це явище суб’єктивне, що складається як відображення соціальних оцінок, думок інших людей, порівняння себе і результатів своїх дій з іншими людьми і результатами їхніх дій. Для 


\section{ПРОФЕСІЙНО-ТВОРЧА САМОРЕАЛІЗАЦІЯ ЗДОБУВАЧІВ ВИЩОЇ ОСВІТИ ЗАСОБАМИ ТРЕНІНГУ}

побудови і усвідомлення “Я-образу” здобувачеві потрібно проаналізувати, як він сприймає інших, як інші сприймають його, а також, які почуття він відчуває з приводу думки інших про себе. Формуючи свій “Я-образ”, особистість соціалізується і самореалізується. Так, вправи з формування “Яобразу” спрямовані на активізацію самоаналізу та отримання “зворотного зв'язку” у психологічно безпечній атмосфері. У ході їх виконання в учасників виробляється почуття поваги до себе й інших людей, а також адекватна (не завищена i не занижена) самооцінка. Для цього усі заняття мають відбуватися винятково у доброзичливій атмосфері, без тиску і повчань. Але, наприклад, емоційно заряджені суперечки під час тренінгуце нормальне явище. Вони можуть підвищити ефективність навчання. Потрібно уважно відстежувати вербальні і невербальні ознаки агресивності.

Наведемо приклад такої вправи, як "Мій Олімп”. Інструкція: кожен здобувач по черзі розповідає групі про будь-які творчі уміння, навички або справи, що їм особливо вдаються. Важливо спонукати учасників пригадати, коли це виявилося, і якими були почуття з цього приводу.

У ході обговорення можна використати такі запитання: що нового ви дізналися про учасників групи? Що відчували, коли говорили самі і коли слухали інших? Чия розповідь вас особливо зацікавила? тощо.

Не менш цікавою, з огляду на наш досвід, вважаємо і таку вправу, як “Я-вчора”, “Ясьогодні”, “Я-завтра”. Інструкція. Намалюйте три малюнки, сутність яких розкривала б три питання (назву вправи). Можна зображати і навколишні предмети, але головне - відобразити себе. Якість малюнка значення не має.

Обговорення. Під час тренінгу учасники представляють свої малюнки на загальний огляд (можна їх розмістити на стенді, фліпчарті тощо). За малюнками здобувачам пропонується відповісти на такі питання: який “Я-вчора”? Який “Я-сьогодні”? У чому основні відмінності “Язавтра” від “Я-вчора”? Як можна наблизити себе до успіхів у професійно-творчому зростанні і що я для цього можна зробити з трьома “Я”: що для цього я буду робити у майбутньому? Ким я буду? Як цього досягти? Що я зараз роблю для цього?

Саме завдяки організації тренінгової роботи та iii змістовому інтерактивному наповненню відбувається розвиток здатності до творчості. Підкреслимо і значення у цьому такого поняття, як креативність - пошук незвичайних шляхів до досягнення мети, бачення світу по-особливиму.

У сучасному світі здобувачі вищої освіти змушені швидко змінюватися, невпинно зростати і розвиватися, щоб бути затребуваними у суспільстві. Креативність створює сприятливі умови для їх цілісного розвитку, саморозкриття, самодостатності і самореалізації.

У найзагальнішому вигляді креативність розуміється як загальна здатність до творчості. Креативність - це творчі можливості людини, що можуть проявлятися у мисленні, почуттях, спілкуванні, окремих видах діяльності, характеризувати особистість загалом і / або iï окремі сторони, продукти діяльності, процес їх створення.

Цікавим є те, що у наукових джерелах [3], [6], у визначенні суті креативності акцент робиться на:

a) продукти, що створені завдяки їй: креативність як здатність породжувати щось нове й оригінальне;

б) процеси: креативність як різновид творчого мислення, високорозвиненої уяви, естетичне світосприйняття;

в) особистісні якості: креативність як відкритість до нового життєвого досвіду, незалежність, динамічність, оригінальність, самобутність особистості;

г) зовнішні умови: креативність як здатність продуктивно діяти у ситуаціях 3 високим ступенем невизначеності, де відсутні заздалегідь відомі алгоритми, гарантовано ведуть до успіху.

Визначимо низку особливостей креативності здобувачів вищої освіти:

- по-перше, поле для прояву креативності-це не лише різновид діяльності, що традиційно належить до творчості (малювання, мистецтво, гра на сцені), а й будь-які життєві ситуації, де є новизна і невизначеність;

- по-друге, креативність - це не одинична здатність, а комплекс особливостей інтелекту і якостей особистості, а також загальна життєва позиція людини. Вона не зводиться ні до якостей, ні до спеціальних творчих здібностей (художніх, музичних тощо);

- по-третє, креативність неспецифічна, вона не $\epsilon$ жорстко пов'язаною $з$ конкретними видами діяльності, а може активізуватися у різних ситуаціях. Її тренування в одному виді діяльності приводить до того, що вона починає яскравіше виявлятися і в інших;

- по-четверте, креативність тією чи іншою мірою властива усім людям, а не є унікальною психологічною якістю.

Отже, професійно-творча самореалізація здобувачів вищої освіти - це складне явище, що виявляється у професійних здібностях 
майбутнього фахівця та базується на творчості, креативності та прагненні проявляти власний потенціал, втілюючи його у процес продуктивної діяльності. I, відповідно, тренінг, у цьому контексті визначаємо як вдалу форму взаємодії зі здобувачами вищої освіти для відпрацювання певних професійних компетентностей і творчого пошуку власних можливостей.

Висновки 3 даного дослідження i перспективи подальших розвідок у даному напрямку. Представлена нами стаття не претендує на остаточне розв'язання проблеми. Перспективу подальших наукових розвідок вбачаємо у розробленні комплексу тренінгових вправ "Професійно-творче зростання i самореалізація” та їх впровадження в освітній процес для здобувачів педагогічних і не педагогічних спеціальностей.

\section{ЛІТЕРАТУРА}

1. Долинська, Л. В., Пенькова, О. І. Самореалізація особистості як соціально-психологічний феномен. Науковий часопис Національного педагогічного університету імені М. П. Драгоманова. Сер. 12: Психологічні науки: зб. наук. працьь. Київ : НПУ імені М. П. Драгоманова, 2016. № 3 (48). С. 18-25.

2. Єрьоміна, Л. Є. Соціальна робота: практикум: навчально-методичний посібник для здобувачів вищої освіти першого (бакалаврського) рівня / за заг.ред. Л. Ю. Москальової. 2020. Мелітополь : ФОП Однорог Т. В., 91 с.

3. Остапчук, О. Професійно-творча самореалізація майбутнього вчителя засобами рефлексивного проектування. Педагогічні інноващіi: iдеї, реалї, перспективи. 2016. Вип. 2. С. 6-18.

4. Педагогічний професіоналізм як наукова категорія. Педагогічна творчість, майстерність, професіоналізм у системі підготовки освітянських кадрів: здобутки, пошуки, перспективи : монографія / керівн. авт. кол. Н. В. Гузій. Київ : Вид-во НПУ імені М. П. Драгоманова, 2015. C. 109-155.

5. Рибалко, Л. С., Черновол-Ткаченко, Р. І., Твердохліб, Г. В. Професійна самореалізація педагогів: іншомовне освітнє середовище, технологія самореалізації вчителів іноземної мови. 2019. Харків : Вид. група “Основа”, 112 с.

6. Самореалізація пізнавально-творчого i професійного потенціалу особистості в інноваційній освіті : монографія / за ред. проф. М. О. Лазарєва. Суми : ФОП Цьома С. П., 2016. 296 с.

\section{REFERENCES}

1. Dolynska, L. V. \& Penkova, O. I. (2016). Samorealizatsiia osobystosti yak sotsialnopsykholohichnyi fenomen [Self-realization of personality as a socio-psychological phenomenon]. Scientific journal of the National Pedagogical University named after Mykhaylo Drahomanov. Ser. 12: Psychological Sciences: Coll. Science. works. Kyiv, No. 3 (48). pp. 18-25. [in Ukrainian].

2. Ieromina, L. Ye. (2020). Sotsialna robota: praktykum: navchalno-metodychnyi posibnyk dlia zdobuvachiv vyshchoi osvity pershoho (bakalavrskoho) rivnia [Social work: workshop: educational and methodical manual for applicants for higher education of the first (bachelor's) level]. (Ed.). L. Yu. Moskalova. Melitopol, 91 p. [in Ukrainian].

3. Ostapchuk, O. (2016). Profesiino-tvorcha samorealizatsiia maibutnoho vchytelia zasobamy refleksyvnoho proektuvannia [Professional and creative self-realization of the future teacher by means of reflective design]. Pedagogical innovations: ideas, realities, perspectives. Vol. 2. pp. 6-18. [in Ukrainian].

4. Pedahohichnyi profesionalizm yak naukova katehoriia. Pedahohichna tvorchist, maisternist, profesionalizm u systemi pidhotovky osvitianskykh kadriv: zdobutky, poshuky, perspektyvy : monohrafiia [Pedagogical professionalism as a scientific category. Pedagogical creativity, skill, professionalism in the system of educational training: achievements, searches, prospects]. (Ed.).V. Huzii. Kyiv, 2015. pp. 109-155. [in Ukrainian].

5. Rybalko, L. S., Chernovol-Tkachenko, R. I. \& Tverdokhlib, H. V. (2019). Profesiina samorealizatsiia pedahohiv: inshomovne osvitnie seredovyshche, tekhnolohiia samorealizatsii vchyteliv inozemnoi movy [Professional self-realization of teachers: foreign language educational environment, technology of selfrealization of foreign language teachers]. Kharkiv, 112 p. [in Ukrainian].

6. Samorealizatsiia piznavalno-tvorchoho i profesiinoho potentsialu osobystosti $\mathrm{v}$ innovatsiinii osviti (2016). [Self-realization of cognitive-creative and professional potential of the individual in innovative education]. (Ed.). M. O. Lazarieva. Sumy, 296 p. [in Ukrainian].

Стаття надійшла до редакції 18.03.2021

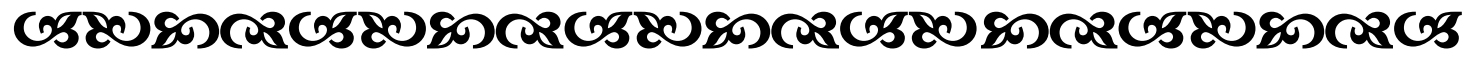

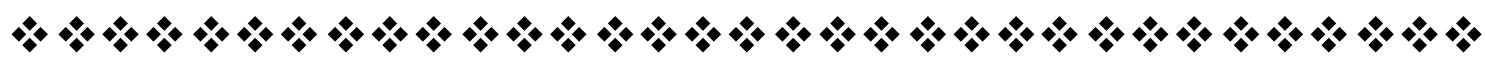

